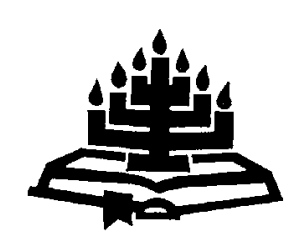

\title{
Die Gereformeerde Skrifbeskouing en die verrekening van die sosiohistoriese konteks in die eksegeseproses
}

\author{
N. Grönum \& F.J. Janse van Rensburg \\ Skool vir Bybelwetenskappe en Bybeltale \\ Noordwes-Universiteit \\ Potchefstroomkampus \\ POTCHEFSTROOM \\ E-pos: gronumnh@hotmail.com \\ sbbjjjvr@puk.ac.za
}

\begin{abstract}
The Reformed view of Scripture and the utilisation of the sociohistoric context in the process of exegesis

At present the issue whether and how the socio-historic context of parts of Scripture should be utilised in the process of exegetical interpretation is being debated in certain circles within the GKSA. This debate includes the issue whether the use of individual cups during Holy Communion services is Scripturally correct, and whether women should be allowed to serve in church offices. The construction of an applicable sociohistoric context as well as the way in which data from this construction are utilised will probably have a decisive effect on the outcome of the debate. The argument developed in this article does not primarily cover the content matter of the debate. The aim of the article is rather to focus on the fundamentals of the Reformed view of Scripture and to determine the necessity of utilising the socio-historic context in the process of exegesis. Consequently it is also an attempt to formulate the applicable implications of such an approach in the process of exegesis.
\end{abstract}

\section{Opsomming}

Die Gereformeerde Skrifbeskouing en die verrekening van die sosiohistoriese konteks in die eksegeseproses

Die vraag oor óf en hóé die sosiohistoriese konteks van Skrifdele in die eksegetiese proses van Skrifverklaring verreken moet word, word ernstig gedebatteer in sekere groeperinge binne die GKSA. Hierdie debat raak ook die vraag of die 
gebruik van individuele Nagmaalsbekers Skriftuurlik verantwoord is en of vroue in die besondere dienste mag staan. Die konstruksie van die tersaaklike sosiohistoriese konteks en die wyse waarop inligting vanuit hierdie gekonstrueerde konteks verreken word, sal waarskynlik 'n bepalende uitwerking op die uitslag van die debat hê. In hierdie artikel is die fokus nie primêr op die inhoudelike aspekte van die debat nie. Die doel van die artikel is eerder om op grond van die Gereformeerde Skrifbeskouing te probeer bepaal of die verrekening van die sosiohistoriese konteks in die eksegesetiese proses onontbeerlik is of nie. Op grond van die gevolgtrekking word dan gepoog om tersaaklike implikasies vir die eksegese te formuleer.

\section{Inleiding}

In 'n onlangse gepubliseerde onderhoud maak Floor (2003:11) die volgende stelling:

Watter hermeneutiese model gaan ons gebruik? Vir my is dit die openbaringshistoriese model. By ander modelle is daar die versoeking en die gevaar dat ons buite-Bybelse gegewens van maatskaplike, sosiale, kulturele of politieke aard laat heers oor die Bybelteks.

Hierdie opmerking van Floor is tekenend van een tipe benadering om die sosiohistoriese konteks in die eksegetiese proses te verreken. Hierdie aangeleentheid geniet die afgelope tyd aandag binne sowel die internasionale teologiese gemeenskap (vgl. Garret, 1992; Meeks, 1986) as binne die GKSA (vgl. Van Rensburg, 2000; Vergeer \& Van Rensburg, 1994; Jordaan, 1991).

Die aktualiteit van die verrekening van die sosiohistoriese konteks word verder verhoog deur persepsies van binnegevegte in die GKSA (vgl. Snyman, 1992), waarin die wyse waarop die sosiohistoriese konteks verreken word, ook ter sprake kom. (Vergelyk ook Vergeer [1993] se reaksie op Snyman se artikels.)

Tans word daar in sekere kringe binne die GKSA gedebatteer oor óf en hóé die sosiohistoriese konteks van Skrifdele bewustelik in die verklaring daarvan verreken moet word ten einde uitsluitsel te kry oor ten minste twee verstaansprobleme: die vraag of die gebruik van individuele Nagmaalsbekers Skriftuurlik is, en of vroue in die besondere dienste mag staan (GKSA, 2000:437; 387; GKSA, 2003: 560). Die konstruksie van die tersaaklike sosiohistoriese konteks en die wyse waarop inligting vanuit hierdie gekonstrueerde konteks 
verreken word, sal waarskynlik 'n bepalende uitwerking op die uitslag van die debat hê.

Met hierdie artikel word gepoog om 'n bydrae te lewer tot die oplossing van dié problematiek binne die GKSA, deur op grond van ' $n$ Gereformeerde Skrifbeskouing 1 te bepaal of dit onontbeerlik is om die sosiohistoriese konteks in die eksegeseproses te verreken. Op grond van dié gevolgtrekking word dan gepoog om tersaaklike implikasies vir die eksegese te formuleer.

Die tersaaklike fasette van die Gereformeerde Skrifbeskouing word eers getipeer; daarna word die implikasies daarvan vir die verrekening van die sosiohistoriese konteks in die eksegeseproses geformuleer.

\section{Die Gereformeerde Skrifbeskouing}

\subsection{Die aard van die Skrif}

\subsubsection{Inleiding}

Die term Skrifbeskouing omskryf die voorveronderstellings of bril(le) waardeur die eksegeet die Skrif beskou. Wentsel (1999:332) definieer hierdie brille soos volg: "Onder brillen versta ik apriori's, vooroordelen of - letterlijk vertaald 'vantevorenheden' - die zowel van wijsgerige als confessionele aard zijn."

Die Gereformeerde Skrifbeskouing handhaaf die standpunt van die Reformasie: die Skrif is die selfopenbaring van God aan die mens. Hierdie Skrifbeskouing is die fondament van een van die vaders van die Reformasie, naamlik Calvyn, se teologie (Floor, 1970:5). Dié Skrifbeskouing is ook verwoord in die Drie Formuliere van Eenheid (NGB, 1987; Art. 3-7) en kom na vore in die Skrifhantering van Gereformeerde teoloë binne die GKSA self. Die Gereformeerde Skrifbeskouing word goed saamgevat in die tradisionele spreuk: Sacra Scriptura est Verbum Dei (Die Heilige Skrif is die Woord van God) (Duvenage, 1967:3).

1 Met "Gereformeerde Skrifbeskouing" word bedoel die Skrifbeskouing wat tans gehuldig word in die Gereformeerde Kerke in Suid-Afrika (GKSA), soos onder andere uiteengesit in die artikel van Coetzee, De Klerk en Floor (1980) en in die artikel van Coetzee (1997). 


\subsubsection{Organiese inspirasie}

Die Gereformeerde Skrifbeskouing handhaaf die teorie dat die Skrif organies deur God geïnspireer is (Van der Waal, 1979:6), en dat dit die wyse is waarop God Homself in die Skrif aan die mens openbaar. Die teorie behels dat die boeke van die Bybel deur die Heilige Gees geïnspireer is en wel op 'n spesifieke wyse. Teenoor die meganiese inspirasieteorie handhaaf die organiese inspirasieteorie die siening dat die Skrif nie pasklaar uit die hemel gekom het nie. Ook het die mense wat dit geskryf het, nie soos blote tikmasjiene gefunksioneer nie (Van der Waal, 1979:6). Juis hierdie visie op die wyse waarop die Skrif ontstaan het, is van deurslaggewende belang by die verrekening van die sosiohistoriese konteks van 'n Bybelboek.

Die organiese inspirasieteorie is 'n poging om reg te laat geskied aan die verskillende fasette van die Skrif as die Woord van God. Die Skrif is die openbaring van God in mensetaal, geskryf deur mense wat op so 'n wyse in diens van die Heilige Gees gestaan het dat hulle die Woord van God betroubaar ontvang en opgeteken het (Van Genderen \& Velema, 1993:89). Hierdie teorie stel dat die Skrif 'n $100 \%$ Goddelike boek én tegelykertyd 'n 100\% menslike boek is (Coetzee, 1997:5). Tussen hierdie twee fasette kan onderskei word, maar dit mag nie geskei word nie.

\section{Die Goddelike faset}

Artikel 5 van die Nederlandse Geloofsbelydenis stel dit soos volg: "Hierdie boeke neem ons aan as heilig en kanoniek ... En ons glo sonder enige twyfel wat daarin vervat is ... omdat hulle ook die bewys daarvan in hulleself het ..." Volgens hierdie Belydenis dra die Skrif dus in Homself die getuienis aangaande sy Goddelike aard. Die Skrif bevat dus getuienis oor Homself, sy inspirasie en sy gesag. Die begronding van die gesag van die Bybel moet in die Skrif self gesoek word (Duvenage, 1967:25). Daar word verskeie Skrifbewyse ter ondersteuning van die stelling genoem. Die twee mees algemene Skrifbewyse is die volgende:

- 2 Timoteus 3:16: "Die hele Skrif is deur God geïnspireer en het groot waarde om in die waarheid te onderrig, dwaling te bestry, verkeerdhede reg te stel en 'n regte lewenswyse te kweek, ..." (Bybel, 1983 Afrikaanse vertaling).

- 2 Petrus 1:21: “... want geen profesie is ooit deur die wil van 'n mens voortgebring nie. Nee, deur die Heilige Gees meegevoer, 
het mense die woord wat van God kom, verkondig" (Bybel, 1983 Afrikaanse vertaling).

God self is hiervolgens die Een wat deur die Skrif met die gelowiges praat. Dit het tot gevolg dat die Skrif vir die gelowige die enigste basis van gesag is (Coetzee et al., 1980:14). In ooreenstemming hiermee is een van die erfenisse van die Reformasie die beklemtoning van die Sola Scriptura-belydenis wat op sy beurt die inherente gesag (outopistie) van die Skrif beklemtoon (Combrink, 1990:325). Die Gereformeerde dogmatikus, J.H. van Wyk (1995: 247), sluit hierby aan. Hy verklaar dat een van die hartare van die $g$ ereformeerde teologie in sy Skrifgebondenheid gesoek moet word.

\section{Die menslike faset}

Die wyse waarop die boeke van die Bybel volgens die organiese inspirasieteorie deur God die Heilige Gees geïnspireer is, is dat die Skrif in mensetaal deur middel van skrywers tot die gelowige kom.

Die verhouding tussen die Heilige Gees as eintlike Outeur en die mensskrywers as openbaringsinstrumente word deur Honig (1938: 94) treffend onder woorde gebring:

De Heilige Geest nam hunne geheele persoonlijkheid in dienst en vandaar het verschijnsel, dat het altoos de Heilige Geest is, die spreek, maar zoo, dat het eigenaardige, het persoonlijke van den schrijver niet dood gedrukt wordt maar in alles uitkomt.

Die Heilige Gees het die skrywers dus binnegedring en hulle op so 'n wyse diensbaar gestel dat hulle steeds self dink, oordink, spreek en skryf (Bavinck, 1895:346).

God openbaar Homself en sy wil in die Skrif aan die wêreld. In die wyse van openbaring het God dit goedgedink om mense te gebruik om sy openbaring op skrif te stel. Hierdie persone was egter nie willoos nie; so ook was die teboekstelling van die openbaring nie sonder enige eie en dikwels unieke persoonlikheidstrekke van die skrywers nie. Hulle was mense wat in verskillende eeue geleef het terwyl elkeen ook met betrekking tot agtergrond, literêre aanpak, persoonlikheid en talente verskil het. Hierdie tipe verskille kom ook na vore in die boeke van die Bybel.

\subsubsection{Die Heilige Gees as Eksegeet}

Die eksegeet wat bely dat die Heilige Gees die Skrif geïnspireer het, moet ook bely dat dieselfde Heilige Gees die onmisbare Eksegeet van die Skrif is (Coetzee et al., 1980:21). 
Skrifdele op grond waarvan die Heilige Gees as die eintlike Eksegeet beskou word, is veral:

- Johannes 14:25-26: "Dit sê ek vir julle terwyl Ek nog by julle bly; en wanneer die Vader in my Naam die Voorspraak, die Heilige Gees, stuur, sal Hy julle alles leer en julle herinner aan alles wat Ek vir julle gesê het" (Bybel, 1983 Afrikaanse vertaling).

- Johannes 16:13: "Wanneer Hy kom, die Gees van die Waarheid, sal Hy julle in die hele waarheid lei. Wat Hy sal sê, sal nie van Homself kom nie: Hy sal net sê wat Hy hoor, en Hy sal die dinge wat gaan kom, aan julle verkondig" (Bybel, 1983 Afrikaanse vertaling).

Die Heilige Gees is dus nie net die eintlike Outeur nie, maar ook die eintlike Interpreteerder. Gereformeerde eksegete wat hulleself ten doel stel om die Skrif te interpreteer, kan dit dus nie in eie krag doen nie, maar moet hulle Skrifverklaring aanpak in biddende afhanklikheid van God onder leiding van die Heilige Gees.

'n Verdere afleiding kan gemaak word op grond van die feit dat al die boeke van die Bybel dieselfde eintlike Outeur het: die Skrif weerspreek homself nooit. Vermeende weersprekings binne die Skrif is die gevolg van die mens se onvermoë om dié gedeeltes geldig te interpreteer (Greijdanus, 1946:50).

\subsection{Die eenheid van die Skrif}

Die eenheid van die Skrif as voorveronderstelling is gegrond op dit wat pas hierbo beredeneer is, naamlik dat die Heilige Gees die eintlike Outeur en Eksegeet van die Skrif is. Alhoewel die Skrif 'n eeue oue biblioteek van verskillende geskrifte is, lê die eenheid in die stelling dat dit een Outeur het (Peels, 1996:61). Grosheide (1929:37) se stelling dat die Heilige Gees as outeur die grondslag vorm vir die belydenis aangaande die eenheid van die Skrif, beklemtoon die feit dat die Gereformeerde Skrifbeskouing te midde van die diversiteit van die Skrif 'n definitiewe eenheid bely.

'n Belangrike hermeneutiese reël wat voortvloei uit die geïnspireerde karakter van die Skrif en die eenheid van die Skrif wat daarmee gepaard gaan, is die gebruik van Skrif-met-Skrif-vergelyking by die interpretasie van 'n Skrifdeel of 'n -tema. Hiermee hang saam die tweede belangrike hermeneutiese reël, naamlik dat daar by die verstaan van die Skrif vanaf die duidelike na die minder duidelike beweeg moet word. So 'n verklaringsmetode behels dat daar met behulp van Skrif-met-Skrif-vergelyking groter duidelikheid oor 'n 
onduidelike uitspraak oor 'n saak gekry moet word vanuit 'n duidelike uitspraak elders in die Skrif oor dieselfde saak (Coetzee et al., 1980:20).

\subsection{Die onderskeiding tydgerig en tydgebonde}

Alhoewel die Skrif nie tydgebonde is nie, is dit wel tydgerig. Hierdie onderskeid tussen tydgebondenheid en tydgerigtheid word met omsigtigheid binne die Gereformeerde Skrifbeskouing gehandhaaf.

Die term tydgerig beskryf die standpunt dat die Skrifopenbaring van God wel gerig is op 'n spesifieke tyd en historiese situasie. Die erkenning van die tydgerigtheid van die Skrif doen egter geen afbreuk aan die gesag en voortgesette geldigheid daarvan nie (Van Genderen \& Velema, 1993:100).

Wie die tydgerigte aard van die Skrif bely, moet dus ook bely dat besondere moeite met die navorsing van die sosiohistoriese milieu in die eksegeseproses gedoen moet word: die "tyd" waarop die betrokke Skrifdeel "gerig" is, moet optimaal in berekening gebring word om die openbaring in die betrokke Skrifdeel geldig te ontleed. lemand wat die teks losmaak van sy historiese agtergrond en geïsoleerd daarvan wil verklaar, loop die gevaar om die Skrif te laat buikspreek en maak inderwaarheid misbruik van die Skrif (Peels, 1996:83).

\subsection{Die helderheid (perspicuitas) van die Skrif}

Ten einde te verstaan wat die Reformasie bedoel het met die helderheid van die Skrif, moet gekyk word na die agtergrond waarteen die stelling dat die Skrif helder is, tot stand gekom het.

Rome het de facto die duisterheid van die Skrif bely. Titus Flavius Klemens, een van die grootste figure van die Aleksandrynse skool, het bely dat die Skrif sy eie betekenis wegsteek (Kaiser \& Silva, 1994:218). Die Skrif is volgens hom 'n duistere en moeilik verstaanbare geskrif wat deur middel van allegorieë verstaanbaar gemáák moes word. Hierteenoor bely die Reformasie die helderheid/deursigtigheid van die Skrif. Die deursigtigheid van die Skrif hou in dat die boodskap van verlossing en genade in Christus so helder en duidelik in die Skrif opgeteken staan dat dit duidelik verstaanbaar is (Coetzee, 1997:11). Bavinck (1895:394) is ook van mening dat die helderheid van die Skrif daarop dui dat die kennis wat nodig is vir verlossing, helder en duidelik is vir elkeen sonder onderskeid. 
Bavinck (1895:394) erken egter dat daar gedeeltes in die Skrif is wat die menslike verstand te bowe gaan en dat daar gedeeltes is wat definitiewe eksegetiese arbeid vereis ten einde geldig verstaan te word. Die Reformatoriese uitgangspunt dat die Skrif helder is, impliseer nie dat elke lettertjie en sinnetjie binne die Skrif verstaanbaar is nie. So 'n siening dui op 'n mistasting en onjuiste voorstelling van die Reformasie se standpunt oor die helderheid van die Skrif.

Greijdanus (1946:22) sluit ten nouste by hierdie standpunt van Bavinck aan deur te sê dat die mens se verstaansvermoë so verduister is deur die sondeval, dat hyself nie die volle rykdom van die Skrif in sy geheel kan ontsluit nie. Daarteenoor is die boodskap van verlossing so eenvoudig en duidelik dat elke gelowige, gelei deur die Heilige Gees, dit kan lees, verstaan en glo.

Die helderheid van die Skrif moet dus in samehang met die verligtende werk van die Heilige Gees gesien word. Honig (1938:122) haal in hierdie verband 1 Korintiërs 2:14 aan: "Die mens wat nie die Gees van God het nie, aanvaar nie die dinge van die Gees van God nie. Vir hom is dit onsin. Hy kan dit ook nie verstaan nie, omdat dit geestelik beoordeel moet word" (Bybel, 1983 Afrikaanse vertaling). Op grond van dié Skrifdeel is hy van mening dat elke sondige mens die boodskap van verlossing in die Skrif kan lees deur die verligtende werk van die Heilige Gees.

\subsection{Die openbaringshistoriese interpretasie}

God het sy wil gaandeweg al hoe duideliker in die loop van die geskiedenis openbaar. Dit behels onder andere dat 'n latere openbaring in die Skrif oor 'n spesifieke aangeleentheid - juis by skynbare weerspreking - deurslaggewender is as 'n vroeëre Skrifuitspraak (Coetzee et al., 1980:20). Dit spreek vanself dat die eksegeet deeglik rekening moet hou met die openbaringshistoriese (of: heilshistoriese) situasie van elke teks.

Slawerny kan as voorbeeld genoem word. Dit mag lyk asof slawerny 'n aanvaarbare praktyk vir Christene behoort te wees as die Skrifgegewens hieroor slegs in Abraham se tyd in ag geneem word. Die brief aan Filemon lui egter die era in wat uiteindelik die einde van hierdie praktyk sou noodsaak (Coetzee, 1997:13).

Dit is belangrik dat die eksegeet deeglik verreken dat daar groei in God se openbaring is wanneer Skrif-met-Skrif-vergelyking gedoen word. Vanweë die openbaringshistoriese situasie kan Ou-Testamentiese tekste nie sonder meer as gelykgeskakel met Nuwe- 
Testamentiese tekste beskou word nie (Van Wyk, 1980:13). Skrifuitsprake wat in hierdie verband ter fundering aangehaal word (bv. Peels, 1996:85), sluit die volgende in:

- Hebreërs 1:1: "In die verlede het God baie keer en op baie maniere met ons voorvaders gepraat deur die profete, ..." (Bybel, 1983 Afrikaanse vertaling).

- Eksodus 6:2: "Ek het aan Abraham, Isak en Jakob verskyn as God die Almagtige, maar my Naam, die Here, het Ek nie aan hulle bekend gemaak nie" (Bybel, 1983 Afrikaanse vertaling).

Die eksegeet wat getrou wil bly aan die Gereformeerde Skrifbeskouing sal dus in sy eksegetiese arbeid daarna moet streef om nie net die sosiohistoriese konteks te verreken nie, maar ook die openbaringshistoriese lyn in die Skrif met betrekking tot die Skrifdeel wat bestudeer word.

\subsection{Gevolgtrekking}

Hierdie tipering van die Gereformeerde Skrifbeskouing laat blyk dat die geskiedenis as sodanig nie binne hierdie beskouing vervlugtig nie. Meer spesifiek word erken dat die sosiale, politieke en godsdienstige omstandighede van die ontstaanstyd van die verskillende boeke van die Bybel as van besondere belang geag word vir 'n geldige verklaring van 'n betrokke Skrifdeel.

\section{Die implikasie van die Gereformeerde Skrifbeskouing vir die verrekening van die sosiohistoriese konteks in eksegese}

\subsection{Inleiding}

Op grond van die tipering van die tersaaklike fasette van die Gereformeerde Skrifbeskouing word vervolgens gepoog om die implikasies van hierdie Skrifbeskouing te verwoord vir die verrekening van die sosiohistoriese konteks in die proses van eksegese. Elke implikasie word eers geformuleer en dan toegelig.

\subsection{Implikasie een}

- Die Gereformeerde Skrifbeskouing impliseer dat die verrekening van die sosiohistoriese konteks onontbeerlik is vir die eksegese van Skrifgedeeltes. 
Die Gereformeerde Skrifbeskouing erken naas die Goddelike aard van die Skrif ook die menslike aard daarvan. So 'n beskouing onderskryf die organiese inspirasieteorie. As die verrekening van die sosiohistoriese konteks in die eksegese nagelaat word, impliseer dit die ontkenning van die belydenis dat die Skrif ook 'n menslike aard het. Dan sou die inspirasie van die Skrif nie meer as organies beskou word nie, maar as meganies. Die verrekening van die sosiohistoriese konteks in die eksegese is onontbeerlik vir die Gereformeerde eksegeet, juis omdat die Gereformeerde Skrifbeskouing erns maak met die belydenis dat die Skrif ook 'n menslike aard het.

\subsection{Implikasie twee}

- Die Skrif is 'n produk van God se aktiwiteit en nie bloot van die tyd van sy ontstaan nie.

Die Gereformeerde Skrifbeskouing bely dat die Heilige Gees die eintlike Outeur van die boeke van die Bybel is. Die Skrif het nie tot stand gekom bloot as gevolg van sosiale, kulturele, ekonomiese of politiese faktore nie. Die Skrif het tot stand gekom omdat Gód gekies het om Homself en sy wil op hierdie wyse aan die mens te openbaar, en dit binne 'n bepaalde kultuur en deur middel van spesifieke individue en/of groepe.

\subsection{Implikasie drie}

- Tye en omstandighede is nie die oorsaak dat die Skrif tot stand gekom het nie, maar beïnvloed wel die wyse waarop God se selfopenbaring tot die mens kom.

Die stelling dat die Skrif nie bloot die produk is van die tyd van sy ontstaan nie, beteken nie dat die tyd en omstandighede van die tyd van sy ontstaan negeerbaar is nie. Die tyd en omstandighede waarbinne elke Bybelboek tot stand gekom het, het 'n baie belangrike invloed op die betrokke boek en was dikwels ook menslik gesproke - die aanleidende oorsaak vir die ontstaan daarvan. Die organiese inspirasieteorie leer immers dat die Skrif 'n $100 \%$ Goddelike en tegelykertyd 'n 100\% menslike aard het.

\subsection{Implikasie vier}

- Die deursigtigheid van die Skrif hou in dat die verrekening van die sosiohistoriese konteks nie tot hermeneutiese sleutel verhef mag 
word nie. Die verrekening van die sosiohistoriese konteks in die eksegeseproses is egter nie om hierdie rede oorbodig nie.

Kennis van die sosiohistoriese konteks van die Skrif is volgens die Gereformeerde Skrifbeskouing nie 'n voorvereiste vir die verstaan van die boodskap van die Skrif nie. Die deursigtigheid van die Skrif behels dat enige mens die Skrif kan lees en daardeur tot kennis aangaande sy redding kan kom. Kennis van die sosiohistoriese konteks en die verrekening daarvan in die eksegeseproses word egter nie om hierdie rede vir die eksegeet oorbodig nie.

Die konstruksie en verrekening van die sosiohistoriese konteks is integraal deel van grammaties-historiese eksegese ${ }^{2}$, saam met stappe soos grammatiese en sintaktiese eksegese, Skrif-met-Skrifvergelyking, openbaringshistoriese eksegese. Net soos wat geen gelowige eers grammatiese eksegese moet kan doen om die boodskap van die Skrif te verstaan nie, net so geld dit van die konstruksie en verrekening van die sosiohistoriese konteks. Nie een van hierdie fasette van grammaties-historiese eksegese word egter om hierdie rede oorbodig nie.

\section{Gevolgtrekking}

Die volgende gevolgtrekkings kan gemaak word:

- As ontken word dat dit onontbeerlik is om die sosiohistoriese konteks in eksegeseproses te verreken, word die Gereformeerde belydenis ontken dat die Skrif ook 'n menslike faset het. De facto kom dit neer op 'n meganiese inspirasieteorie. Dit beteken dat iemand wat betwis dat dit onontbeerlik is om die sosiohistoriese konteks in die eksegeseproses te verreken, de facto nie meer die Gereformeerde Skrifbeskouing handhaaf nie.

- Die verrekening van die sosiohistoriese konteks in die eksegese van 'n Skrifgedeelte is geen hermeneutiese sleutel vir die verstaan van die Skrif nie. Net so kan ander stappe in die grammaties-historiese eksegeseproses ook nie tot hermeneutiese sleutel verhef word nie. Geeneen van hierdie stappe word egter om dié rede oorbodig nie. Elkeen moet sy regmatige plek in die eksegetiese proses inneem.

2 Grammaties-historiese eksgese word as eksegetiese metode gebruik deur predikante in die GKSA en dien tans as basis vir die opleiding van teologiese studente van die GKSA (vgl. De Klerk \& Janse van Rensburg, 1999:1). 
- As 'n mens aanvaar dat die eksegeet geroep is om die boodskap van die Skrif so duidelik as moontlik uit te lê vir gelowiges en hulle toe te rus om die Skrif self te verstaan, is dit vir die Gereformeerde eksegeet onontbeerlik om die sosiohistoriese konteks te verreken in die eksegese.

Die Gereformeerde eksegeet wat erns wil maak met die Gereformeerde belydenis en Skrifbeskouing, word genoodsaak om die sosiohistoriese konteks te verreken - nie omdat die Skrif daarsonder onverstaanbaar sou wees nie, maar omdat die Skrif ook 100\% menslik is. Die Gereformeerde eksegeet wat die Skrif op 'n verantwoordelike wyse wil verklaar, sal reg laat geskied aan die menslike aard van die Skrif deur die sosiohistoriese konteks geldig en verantwoordelik te verreken, in die besef dat die gesag van Skrif aangetas sal word indien die sosiohistoriese konteks van die betrokke Bybelboek nie verreken word nie.

Daarom is dit belangrik dat die sosiohistoriese konteks in die debatte oor die vraag of die gebruik van individuele Nagmaalsbekers Skriftuurlik verantwoord is, en of die vrou in die besondere dienste mag staan, vir die betrokke kerntekste geldig gekonstrueer word. Die inligting wat vanuit hierdie gekonstrueerde konteks verkry word, moet dan op 'n geldige wyse in die eksegese verreken word. Só bly die Gereformeerde eksegeet ook de facto getrou aan die Gereformeerde Skrifbeskouing wat hy/sy bely.

\section{Geraadpleegde bronne}

BAVINCK, H. 1895. Gereformeerde dogmatiek: inleiding, prinsipia. Deel 1. Kampen: Bos.

BERKOUWER, G.C. \& TOORNVLIET, G. 1949. Het dogma der kerk. Groningen: Haan.

BYBEL. 1983. Die Bybel: nuwe vertaling. Kaapstad: Suid-Afrikaanse Bybelgenootskap.

COETZEE, J.C., DE KLERK, B.J., \& FLOOR, L. 1980. Die hermeneuse van die Skrif met die oog op hedendaagse kerklik-etiese vraagstukke. In die Skriflig, 14(54):12-26.

COETZEE, J.C. 1997. Hermeneutics and exegesis of the New Testament. Orkney: EFJS Drukkers.

COMBRINK, H.J.B. 1990. Die krisis van die Skrifgesag in die gereformeerde eksegese as 'n geleentheid. Nederduits Gereformeerde Teologiese Tydskrif, 31:325-335.

DE KLERK, B.J. \& JANSE VAN RENSBURG, F.J. 1999. Preekgeboorte: 'n handleiding vir Gereformeerde eksegese en prediking, toegepas op 1 Petrus 2:11-12, 18-25. Potchefstroom: PU vir CHO. 
DUVENAGE, S.C.W. 1967. Die gesag van die Heilige Skrif. Potchefstroom: PU vir $\mathrm{CHO}$. (Inougurele rede gehou by die aanvaarding van die professoraat in Bybelkunde aan die Potchefstroomse Universiteit vir Christelike Hoër Onderwys, Vrydag 14 April 1967.)

FLOOR, L. 1970. Calvyn se hermeneutiek en sy betekenis vir ons tyd. In die Skriflig, 4(14):3-20.

FLOOR, L. 2003. Die redakteur gesels met prof. Bert Floor. Die Kerkblad: 9-11, Des.

GARRET, S.R. 1992. Sociology of early Christianity. (In The Anchor Bible Dictionary. Vol. 6. New York: Doubleday. p. 89-99.)

GEREFORMEERDE KERKE IN SUID-AFRIKA. 2000. Handelinge van die sewe en veertigste Nasionale Sinode te Potchefstroom op 10 Januarie 2000 en volgende dae. Potchefstroom: GKSA.

GEREFORMEERDE KERKE IN SUID-AFRIKA. 2003. Handelinge van die agt en veertigste Nasionale Sinode te Potchefstroom op 6 Januarie 2003 en GKSA volgende dae. Potchefstroom: GKSA.

kyk Gereformeerde Kerke in Suid-Afrika

GREIJDANUS, S. 1946. Schriftbeginselen ter Schrift verklaring en historisch overzicht over theorieën en wijzen van schriftuitlegging. Kampen: Kok.

GROSHEIDE, F.W. 1929. Hermeneutiek: ten dienste van de bestudeering van het Nieuwe Testament. Amsterdam: Bottenburg.

HONIG, A.G. 1938. Handboek van de Gereformeerde dogmatiek. Kampen: Kok.

JORDAAN, G.J.C. 1991. Skrifbeskouing: deurslaggewende faktor by Skrifverklaring. Potchefstroom: Departement Sentrale Publikasies. (Inougurele rede, Potchefstroomse Universiteit vir Christelike Hoër Onderwys, 7 Junie 1991.)

KAISER, W.C. \& SILVA, M. 1994. An introduction to biblical hermeneutics. Grand Rapids: Zondervan.

MEEKS, W.A. 1986. The moral world of the first Christians. Philadelphia: Westminster.

NEDERLANDSE GELOOFSBELYDENIS. 1987. (In Die berymde Psalms en Skrifberymings. 2de hersiene uitgawe. Kaapstad: NG Kerk-uitgewers.

NGB p. 486-520.)

kyk Nederlandse Geloofsbelydenis

PEELS, H.G.L. 1996. Het Woord is leven - over de Heilige Schrift. (In Van den Brink, G., Van Campen, M., Van der Graaf, J., reds. Gegrond geloof: kernpunten uit de geloofsleer in bijbels, historisch en belijdend perspectief. Zoetermeer: Boekencentrum. p. 52-92.)

SNYMAN, G. 1992. Binnegevegte in die GKSA: verskuiwing van "plausability structures"? In die Skriflig, 26(3):351-367.

VAN DER WAAL, C. 1979. Sola Scriptura: wegwijzer bij het bijbellezen. Deel 1. 3de dr. Goes: Oosterbaan \& Le Cointre.

VAN GENDEREN, J. \& VELEMA, W.H. 1993. Beknopte Gereformeerde dogmatiek. 2de dr. Kampen: Kok.

VAN RENSBURG, F.J. 2000. Dekor of konteks? - Die verdiskontering van sosiohistoriese gegewens in interpretasie van 'n Nuwe Testament-teks vir die prediking en pastoraat, geillustreer aan die hand van die 1 Petrusbrief. Skrif en Kerk, 21(3):564-582. 
VAN WYK, G.J. 1980. 1 Korinthiërs 11: 2-16: 'n Hermeneuties-eksegetiese studie. Potchefstroom: PU vir CHO. (Werkstuk - Th.B.)

VAN WYK, J.H. 1995. Die relevansie van die Gereformeerde teologie vir vandag. In die Skriflig, 29(1 \& 2):241-268.

VERGEER, W. 1993. Teologie en kenteorie. 'n Reaksie op die artikels van Gerrie Snyman. In die Skriflig, 27:563-582.

VERGEER, W.C. \& JANSE VAN RENSBURG, F.J. 1994. Die dwaalleer in Kolosse - 'n Konstruksie van die waarskynlike sosiohistoriese en filosofiese konteks. In die Skriflig, 28(1):1-24.

WENTSEL, B. 1999. Hermeneutiek, Schriftgesag en Triniteit. In die Skriflig, 33(3):331-345.

\section{Kernbegrippe:}

(Gereformeerde) Skrifbeskouing

sosiohistoriese konteks in die eksegetiese proses

Key concepts:

(Reformed) view of Scripture

socio-historic context in the exegetical process 